\title{
PEMANFAATAN MULTIMEDIA PRESENTASI DAN MEDIA CETAK DALAM MENINGKATKAN MUTU PEMBELAJARAN PENDIDIKAN AGAMA HINDU
}

\author{
Oleh \\ I Wayan Sirna \\ SMA Negeri 5 Denpasar \\ iwayansirna@gmail.com \\ Putu Ersa Rahayu Dewi \\ Institut Hindu Dharma Negeri Denpasar \\ ersarahayu@gmail.com
}

Diterima 20 Desember 2017, direvisi 20 Januari 2018, diterbitkan 28 Pebruari 2018

\begin{abstract}
Education is the human necessity and it has major role to gain better life. The education quality depends on the government policy, the societies' role, and schools' efforts to due education. The school is one of the institution that enrolls teaching and learning activity and it needs some components to support its activity. The achievement of educational quality can be seen on the students' progress during teaching and learning process. The students' achievement of Hinduism lesson is quite low caused they had nothing from the subjects that being learned. The Hinduism lesson students' achievement using printed media and multimedia presentation due through classroom management, teaching materials, develop students' learning activity, the assessment of teaching and learning process, and the assessment of comprehending concept/ knowledge, these results raise $20 \%$ from the former results.
\end{abstract}

Key words: Multimedia Presentation, Printed Media, Hinduism lesson teaching and learning, Students' Achievement.

\section{PENDAHULUAN}

Pendidikan menjadi kebutuhan setiap manusia dan memiliki peranan penting dalam meningkatkan taraf hidup manusia. Itu sebabnya, negara Republik Indonesia (RI) melalui kebijakan pemerintah menjamin pemerataan kesempatan pendidikan melalui program wajib belajar 9 tahun dan peningkatan kualitas manusia Indonesia seutuhnya melalui olahdiri agar mampu bersaing dalam menghadapi tantangan hidup era globalisasi ini. Olahdiri adalah upaya pengembangan diri agar tumbuh menjadi manusia yang beriman, berkeperibadian, berlogika, sosial, memiliki 
keterampilan dan rasa estetika, serta sehat jasmani dan rohani.

Perkembangan ilmu pengetahuan dan teknologi yang sangat pesat dewasa ini, seperti perkembangan Teknologi Informasi (TI) mengharuskan lembaga pendidikan untuk selalu berupaya meningkatkan kualitas sumber daya manusia dan sarana-prasarana yang memadai agar selalu dapat mengikuti perkembangan Ilmu Pengetahuan dan Teknologi (IPTEK). Sekolah sebagai lembaga pendidikan formal memiliki tugas dan tanggung jawab dalam meningkatkan kualitas pendidikan nasional yang mengacu pada Permendiknas Nomor 23 Tahun 2006 tentang Standar Kompetensi Lulusan yang terkait dengan standar kompetensi kelompok mata pelajaran, yaitu: agama dan akhlak mulia, kewarganegaraan dan keperibadian, ilmu pengetahuan dan teknologi, estetika, serta jasmani, olah raga, dan kesehatan. Pengembangan potensi siswa berdasarkan standar kompetensi kelompok mata pelajaran pada sekolah menengah dimaksudkan untuk menghasilkan lulusan berkualitas yang berkarakter, kecakapan, dan keterampilan yang memadai dan kuat sehingga mampu berinteraksi dengan lingkungan sosial, budaya, dan alam sekitar, serta mengembangkan kemampuan lebih lanjut dalam dunia kerja atau pendidikan lebih lanjut. Lulusan Sekolah Menengah Atas (SMA) diharapkan memiliki keyakinan dan ketakwaan sesuai dengan ajaran agama yang dianutnya, memiliki nilai dasar humaniora, menguasai pengetahuan dan keterampilan akademik serta beretos belajar untuk melanjutkan pendidikan kejenjang yang lebih tinggi, menerapkan kemampuan akademik dan keterampilan hidup di masyarakat lokal maupun global.

Kelompok mata pelajaran agama dan akhlak mulia seperti yang disebutkan dalam Permendiknas Nomor 23 Tahun 2006 tentang Standar Kompetensi Lulusan bahwa kelompok mata pelajaran agama dan akhlak mulia bertujuan untuk membentuk siswa agar tumbuh dan berkembang menjadi manusia yang beriman dan bertakwa kepada Tuhan Yang Maha Esa serta berakhlak mulia. Sikap dan kemampuan yang diamanatkan dalam kelompok mata pelajaran agama dan akhlak mulia adalah sebagai berikut:

a. Berperilaku sesuai dengan ajaran agama yang dianut dan sesuai dengan perkembangan remaja.

b. Menghargai keberagaman agama, bangsa, suku, ras, golongan sosial ekonomi, dan budaya dalam tatanan global.

c. Berpatisipasi dalam penegakan aturanaturan sosial.

d. Memahami hak dan kewajiban diri dan orang lain dalam pergaulan di masyarakat.

e. Menghargai adanya perbedaan pendapat dan berempati terhadap orang lain.

f. Berkomunikasi dan berinteraksi secara efektif dan santun melalui berbagai cara termasuk pemanfaatan teknologi informatika yang mencerminkan harkat dan martabatnya sebagai makhluk Tuhan.

g. Menjaga kebersihan, kesehatan, ketahanan dan kebugaran jasmani dalam kehidupan sesuai dengan tuntunan agama.

h. Memanfaatkan lingkungan sebagai makhluk ciptaan Tuhan secara bertanggung jawab (Tim Sinar Grafika, 2006: 54).

Tujuan dan kemampuan yang diamanatkan dalam Peraturan Menteri Pendidikan Nasional Nomor 23 Tahun 2006, tentang Standar Kompetensi Lulusan untuk Satuan Pendidikan Dasar dan Menengah tersebut, dapat dicapai melalui proses pembelajaran yang diatur berdasarkan Peraturan Menteri Pendidikan Nasional Nomor 41 tahun 2007 tentang Standar Proses untuk Satuan Pendidikan Dasar dan Menengah. Standar proses meliputi perencanaan proses pembelajar-an, pelaksanaan proses pembelajaran, penilaian hasil pem-belajaran, dan pengawasan proses pembelajaran untuk ter-laksananya proses pembelajaran yang efektif dan efisien. Perencanaan proses pembelajaran meliputi 
silabus dan Rencana Pelaksanaan Pembelajaran (RPP) yang memuat identitas mata pelajaran, Standar Kompetensi (SK), Kompe-tensi Dasar (KD), indikator pencapaian kompetensi, tujuan pembelajaran, materi pembelajaran, alokasi waktu, metode pembela-jaran, kegiatan pembelajaran, penilaian hasil belajar, dan sumber belajar. Pelaksanaan pembelajaran merupakan implementasi dari silabus dan RPP. Pelaksanaan pembelajaran meliputi: kegiatan pendahuluan, kegiatan inti, dan kegiatan penutup. Penilaian dilakukan oleh guru terhadap hasil pembelajaran untuk mengukur tingkat pencapaian kompetensi siswa yang digunakan sebagai bahan penyusunan laporan kema-juan hasil belajar dan memperbaiki proses pembelajaran. Pengawasan terhadap proses pembelajaran dilakukan oleh kepala sekolah dan pengawas satuan pendidikan yang meliputi: pemantauan supervisi, evaluasi, pelaporan, dan tindak lanjut.

Pembelajaran yang efektif dan efisien seperti yang diamanatkan dalam Peraturan Menteri Pendidikan Nasional Nomor 41 tahun 2007 tentang Standar Proses untuk Satuan Pendidikan Dasar dan Menengah tersebut, diperlukan usaha secara bersama-sama oleh semua komponen pendidikan, terutama usaha yang harus dilakukan oleh pendidik atau guru. Salah satu usaha yang dapat dilakukan guru adalah memperbaiki proses belajar mengajar. Pengelolaan proses pembelajaran harus benarbenar melalui suatu perencanaan yang matang, pelaksanaan yang profesional oleh tenaga guru yang profesional, dan didukung oleh saranaprasarana yang memadai. Salah satu bagian penting dari suatu proses pembelajaran adalah menyampaikan materi pembelajaran kepada siswa secara oftimal, agar siswa dapat mengerti, memahami, memaknai, dan menerapkan dalam menjalani kehidupan di masyarakat. Pembelajaran yang dilakukan oleh guru merupakan rangkaian kegiatan mulai dari perencanaan, pelaksanaan pembelajaran, dan penilaian pembelajaran serta program tindak lanjut yang berlangsung dalam situasi yang mendidik sehingga tujuan pembelajaran dapat tercapai.

Pembelajaran yang dilaksanakan oleh guru selama ini, hanya tertuju pada penyelesaian materi pelajaran sesuai dengan alokasi waktu, yang kurang memperhatikan belajar efektif dan bermakna. Pembelajaran efektif adalah upaya pembelajaran yang dapat mencapai hasil sesuai dengan harapan, sedangkan pembelajaran bermakna adalah pembelajaran yang berhubungan dengan pengalaman masa lalu siswa, tujuan-tujuan dimasa yang akan datang, minat, dan nilai-nilai yang berarti untuk siswa. Pembelajaran akan berlangsung efektif apabila pembelajaran yang dilakukan oleh guru menjadi suguhan yang menarik dan menyenangkan para siswa. Belajar menyenangkan merupakan pembelajaran yang dirancang variatif dengan menciptakan suasana belajar yang kondusif seperti tidak mengulang hal-hal yang sudah diketahui siswa, tidak memberikan tugas-tugas yang tidak masuk akal atau diluar jangkauan siswa, menciptakan fisik kelas yang tidak membosankan, dan terhindar dari gangguan emosional kontak personal (Hamalik, 2001: 161).

Proses pembelajaran yang kurang memperhatikan prinsip-prinsip belajar yang efektif, bermakna, dan menyenangkan serta kurang memperhatikan persiapan atau rencana pembelajaran, akan cenderung terpaku pada pola-pola pembelajaran konvensional/ tradisional. Guru akan cendrung menyajikan materi pelajaran berdasarkan hal-hal yang diingat saja, bahkan bisa terjadi kehilangan arah pembelajaran karena tidak didasari dengan persiapan yang matang. Penerapan pembelajaran konvensional/tradisional adalah proses pembelajaran yang dilakukan berdasarkan kebiasaan-kebiasaan sebelumnya yang kurang inovatif dan tanpa memperhatikan perkembangan ilmu pengetahuan dan teknologi di bidang pendidikan. Menurut Elmubarok (2008: 57) pendekatan atau pola-pola 
pembelajaran tradisional cendrung kurang memperhatikan kelangsungan pengalaman siswa yang diperoleh dalam kehidupan keluarga dan lingkungan masyarakat sehingga sulit untuk mencapai tujuan pendidikan. Pembelajaran tradisional juga kurang memperhatikan relevansi, kebermaknaan, dan faktor-faktor yang turut mempengaruhi proses pembelajaran. Guru lebih berorientasi pada hasil belajar bukan pada proses untuk mencapai tujuan belajar. Guru sering mengabaikan pemilihan dan penggunaan media dalam proses pembelajaran, pada hal media merupakan salah satu sumber informasi yang turut serta dalam menentukan pencapaian tujuan pembelajaran.

Pola pembelajaran konvensional/ tradisional yang dimaksudkan dalam penelitian ini, adalah pembelajaran yang menggunakan media tunggal berupa buku teks pelajaran. Buku teks pelajaran dijadikan sebagai satu-satunya sumber belajar untuk mencapai tujuan belajar. Penggunaan media tunggal terlebih berupa buku teks pelajaran yang hanya berupa uraian katakata tentu kurang memperhatikan kondisi dan prinsip-prinsip pembelajaran efektif, bermakna, dan menyenangkan. Siswa akan merasa cepat bosan dan jenuh dalam mengikuti pembelajaran yang disajikan oleh guru. Siswa hanya bisa menghafal sejumlah kata-kata saja tanpa memahami dengan benar sesuatu yang dipelajari dan kemungkinan untuk lupa sangat besar. Hal itulah yang menyebabkan hasil belajar siswa masih sangat rendah.

Hasil belajar atau kualitas pendidikan yang rendah, ditengarai akibat dari kegiatan pembelajaran yang dikuti siswa tidak memperoleh makna dari sesuatu yang dipelajari, sehingga siswa tidak mampu menghubungkan materi pelajaran dengan kehidupan sehari-hari. Keadaan ini ditengarai juga akibat proses pembelajaran yang masih menerapkan pendekatan konvensional/tradisional, yaitu bahwa dalam pembelajaran siswa seolah-olah memiliki kebutuhan yang sama, dan belajar dengan cara yang sama, dalam ruang kelas yang tenang, dengan kegiatan materi pelajaran yang berstruktur secara ketat dan didominasi oleh guru. Sudah selayaknya, para guru di era globalisasi ini untuk menerapkan pembelajaran dengan pendekatan-pendekatan modern seperti dengan memanfaatkan Teknologi Informasi (TI) sebagai media pembelajaran. Pemanfaatan teknologi modern dalam pembelajaran disenyalir mampu menciptakan suasana belajar yang lebih menarik dan menyenangkan sehingga mampu meningkatkan prestasi belajar siswa.

Pembelajaran pendidikan agama, termasuk pendidikan agama Hindu di era teknologi dan globalisasi belum maksimal dalam memanfaatkan suatu media yang tepat untuk memberdayakan indera-indera siswa yang bertipe visual, audio, atau audio-visual. Pembelajaran pendidikan agama Hindu dengan menggunakan media yang tepat dan memiliki kesesuaian antara materi pembelajaran dengan kehidupan keseharian siswa akan lebih mudah dipahami atau dimengerti. Penggunaan media yang tepat, bervariasi, dan praktis di era globalisasi ini yang dimaksud adalah pemanfaatan TI berupa multimedia pembelajaran. Pembelajaran dengan multimedia akan memberikan suguhan yang menyenangkan pada siswa yang dapat menarik perhatian dan meningkatkan motivasi untuk belajar. Media pembelajaran memiliki peran yang penting dalam mengatur hubungan yang efektif dalam proses belajar yaitu hubungan siswa dengan isi pelajaran. Arsyad (2008: 8) menyatakan, agar proses belajar mengajar dapat berhasil dengan baik, siswa sebaiknya diajak untuk memanfaatkan semua alat inderanya dengan memanfaatkan berbagai jenis media yang berkaitan dengan materi pelajaran. Guru berupaya untuk menampilkan rangsangan (stimulus) yang dapat diproses dengan berbagai indera. Pemberdayaan semua alat indera dalam menerima dan mengolah informasi akan semakin baik informasi tersebut dimengerti dan dapat dipertahankan dalam ingatan.

Ada beberapa faktor yang turut 
mempengaruhi proses pembelajaran, yaitu (1) faktor intern yaitu faktor yang berasal dari diri individu, seperti faktor jasmani dan faktor psikologis; (2) faktor ekstern yaitu faktor yang berasal dari luar individu, seperti faktor keluarga, faktor sekolah, dan faktor masyarakat. Proses pembelajaran di sekolah terdapat aktivitas peran guru dan siswa. Peran guru dalam pembelajaran adalah menyusun rencana pembelajaran, melaksanakan pembelajaran dan menilai proses pembelajaran. Penyusunan dan pelaksanaan proses pembelajaran tentu diperlukan teknologi sebagai prinsip untuk meningkatkan hasil belajar. Teknologi yang dimaksud adalah sebatas pada hasil teknologi dalam bidang pendidikan seperti teknologi informasi berupa perangkat komputer. Perangkat komputer terdiri dari perangkat keras dan perangkat lunak yang menjadi fasilitas dalam merancang media pembelajaran dengan meramu beberapa jenis media yang disebut dengan multimedia.

Era teknologi dan globalisasi mengharuskan para pelaku pendidikan untuk memanfaatkan hasil teknologi dalam proses pembelajaran sebagai upaya untuk meningkatkan tujuan pendidikan seperti yang diamanatkan dalam Undang-Undang Pendidikan. Pemanfaatan hasil teknologi dalam bidang pendidikan termasuk pada proses pembelajaran pendidikan agama Hindu di Sekolah Menengah Atas (SMA). Pemanfaatan hasil teknologi dalam bidang pendidikan seperti multimedia presentasi melalui software powerpoint akan memberikan hasil positif terhadap peningkatan kualitas pendidikan. Pemanfaatan teknologi pendidikan dalam proses pembelajaran, harus memperhatikan faktor-faktor yang mempengaruhi dan juga melakukan upaya-upaya yang turut mendukung pemanfaatan multimedia presentasi melalui software powerpoint dalam rangka mencapai tujuan pembelajaran.

\section{METODE}

Lokasi penelitian yang dipilih adalah di SMA Negeri 5 Denpasar, dengan alasan: Pertama, SMA Negeri 5 Denpasar memiliki fasilitas pembelajaran yang memadai, seperti tersedianya perangkat komputer dan Liquid Crystal Display (LCD) sehingga sangat memungkinkan guru-guru melakukan pembelajaran dengan memanfaatkan fasilitas tersebut. Kedua, guru pendidikan agama Hindu di SMA Negeri 5 Denpasar selama ini belum memanfaatkan fasilitas yang tersedia secara efektif untuk meningkatkan hasil belajar siswa.

Jenis penelitian yang digunakan dalam penelitian ini adalah jenis penelitian kualitatif, dengan sumber data primer dan data sekunder. Data primer dikumpulkan dari lapangan dengan cara melakukan observasi dan wawancara dilakukan untuk mendapatkan data primer. Sedangkan data sekunder adalah data penunjang yang didapat dari literatur-literatur tentang pembelajaran atau hasil penelitian sejenis yang pernah dilakukan sebelumnya dan dokumen yang berasal dari tempat penelitian.

Metode yang digunakan untuk mengumpulkan data dalam penelitian ini adalah: observasi, wawancara, dan studi dokumentasi dan kepustakaan. Data yang terkumpul dalam penelitian ini berupa pernyataan-pernyataan atau rangkaian kata-kata, maka analisis data dilakukan dengan analisis kualitatif. Analisis kualitatif menggunakan teknik non statistik, yaitu dengan proses berpikir induktif.

\section{PEMBAHASAN}

\subsection{Gambaran Umum Pemanfaatan Multimedia Presentasi dan Media Cetak dalam Pembelajaran Pendidikan Agama Hindu}

Tiga hal yang strategis dalam kegiatan pembelajaran adalah komponen guru, siswa, dan kurikulum. Apabila salah satu dari 
komponen tersebut tidak ada, maka proses pembelajaran tidak mungkin dapat dilaksanakan. Namun pembelajaran akan berhasil dengan optimal apabila didukung dengan sarana-prasarana yang memadai, salah satunya adalah media pembelajaran yang sesuai dengan materi pembelajaran yang dapat memfasilitasi pembelajaran yang efektif, bermakna, dan menyenangkan. Penelitian ini memaparkan tentang pembelajaran yang memanfaatkan multimedia presentasi dan media cetak.

Pembelajaran dengan multimedia adalah pelaksanaan pembelajaran dengan menggunakan beberapa jenis media seperti teks, gambar/bagan/grafik, foto, audio/suara, dan video. Kombinasi beberapa media ini dapat disajikan dengan bantuan perangkat komputer melalui software powerpoint yang selanjutnya disebut dengan multimedia presentasi. Pembelajaran dengan multimedia presentasi adalah penyajian isi pelajaran dengan teks sekaligus dengan gambar, suara, dan video. Cara kerja penyajian ini yaitu guru menyajikan isi pelajaran dengan silde-slide powerpoint yang diproyeksikan ke layar lebih besar dengan menggunakan Liquid Crystal Display (LCD). Melalui slide-slide yang telah berisi rancangan isi pelajaran, guru memfasilitasi dan mengarahkan pembelajaran dengan metodemetode yang telah ditentukan untuk pencapaian kompetensi belajar siswa.

Multimedia presentasi memiliki keunggulan dalam kegiatan pembelajaran di kelas dibandingkan dengan menggunakan media tunggal seperti dengan media cetak saja. Multimedia presentasi yang digunakan dalam pembelajaran pendidikan agama Hindu pada siswa SMA Negeri 5 Denpasar adalah untuk mengakomodasi berbagai gaya atau tipe belajar siswa, karena multimedia presentasi dirancang dengan kombinasi beberapa media yang saling melengkapi kekurangankekurangan dari masing-masing media tunggal. Pembelajaran dengan menggunakan multimedia presentasi dapat merangsang siswa belajar lebih aktif dan interaktif dalam menanggapi pesanpesan yang disajikan berupa visual, audio, dan video. Selain itu, multimedia presentasi mampu menjadikan suasana pembelajaran yang lebih menarik dan menyenangkan sehingga siswa tidak mudah bosan atau melelahkan.

Pemanfaatan multimedia presentasi dan media cetak (buku teks pelajaran digunakan secara terpadu dalam pembelajaran, sehingga dapat mengantarkan proses komunikasi menjadi berhasil. Multimedia presentasi mampu mengatasi hambatan-hambatan gaya atau tipe belajar siswa. Sumber pesan bisa penulis buku, pelukis, fotografer, produser, dan guru sendiri. Media bisa berupa isi buku, gambar, foto, program kaset, audio, VCD yang diramu dalam bentuk multimedia. Guru sebagai fasilitator penyampai pesan. Guru dan media bekerja sama, bahu mambahu dalam menyajikan pesan kepada siswa.

Walaupun pemanfaatan multimedia presentasi dalam pembelajaran memiliki beberapa keunggulan, akan tetapi guru atau pendidik tidak luput dari hambatan-hambatan baik hambatan dalam pengadaan perangkat komputer, perancangan multimedia, maupun pengelolaan dalam pelaksanaan pembelajaran. Guru tidak akan serta merta langsung dapat menggunakan perangkat keras dan perangkat lunak komputer, melainkan harus melalui proses pelatihan mengoperasikan perangkat komputer dan latihan perancangan media pembelajaran dengan menggunakan program powerpoint. Demikian juga halnya dalam pelaksanaan pembelajaran memerlukan kemampuan untuk mengelola media yang dihasilkan yaitu berpindah dari slide yang satu ke slide yang lainnya, agar pembelajaran dapat berlangsung secara efektif dan sistematis.

Pemanfaatan media cetak dalam pembelajaran merupakan kegiatan pembelajaran yang paling sering dilakukan oleh guru-guru yang kurang inovatif dan kreatif. Hal ini sering dilakukan, karena kurangnya persiapan 
dalam pembelajaran. Media cetak dalam pembelajaran yang selalu digunakan oleh guru dan siswa adalah berupa buku teks pelajaran. Buku teks pelajaran memuat isi pelajaran berupa uraian kata-kata yang panjang dan berupa gambar-gambar. Gambar-gambar yang disajikan sering dalam bentuk hitam-putih dan kurang jelas. Penyajian isi pelajaran seperti itu akan cendrung membuat siswa cepat bosan dalam belajar.

Pembelajaran dengan hanya menggunakan buku teks pelajaran sebagai sumber belajar, guru tidak terlalu sulit menyusun persiapan pembelajaran. Berbekal buku teks pelajaran seorang guru dapat melaksanakan proses pembelajaran di kelas dengan dominasi metode ceramah variasi. Pembelajaran yang hanya menggunakan media cetak (buku teks pelajaran) guru berusaha untuk menyelesaikan materi pelajaran tanpa memperhatikan gaya atau tipe belajar siswa sehingga sering mengalami kegagalan dalam belajar mengajar.

Guru mendeskripsikan informasi atau pesan yang terdapat pada buku teks pelajaran. Hanya siswa A yang memiliki kepekaan audio yang relevan yang mampu menafsirkan pesan yang disampaikan guru, siswa A1 dan A2 yang memiliki kepekaan audio yang kurang dan mengalami kesulitan didalam menafsirkan pesan-pesan yang disampaikan guru, sedangkan siswa B mengalami kegagalan dalam menafsirkan pesan-pesan yang disampaikan guru. Terlepas dari isu siswa yang bodoh dan pintar, keadaan seperti inilah yang sering terjadi pada kasus guru. Siswanya mengalami kesulitan dan kegagalan dalam menafsirkan pesan-pesan yang disampaikan.

Pemanfaatan jenis media dalam pembelajaran pendidikan agama Hindu pada siswa SMA Negeri 5 Denpasar, bukan dilakukan secara terpisah melainkan digunakan secara bersamaan dalam pembelajaran pendidikan agama Hindu terkait dengan penelitian ini. Pembelajaran dengan menggunakan multimedia presentasi dan media cetak (buku teks pelajaran) tersebut adalah agar pembelajaran dapat mengakomodasikan berbagai gaya atau tipe belajar siswa. Pemanfaatan multimedia presentasi bertujuan untuk mempermudah memahami isi pelajaran yang terdapat dalam buku teks pelajaran, sedangkan buku teks pelajaran diperlukan sebagai bahan ajar. Bahan ajar merupakan seperangkat materi pembelajaran yang disusun secara sistematis, menampilkan sosok utuh dari kompetensi yang akan dicapai siswa dalam kegiatan pembelajaran. Tersedianya bahan ajar memungkinkan siswa dapat mempelajari suatu kompetensi secara runtut dan sistematis. Buku teks pelajaran yang digunakan sebagai bahan ajar tidak dilengkapi dengan ilustrasi atau gambar-gambar yang memadai sehingga siswa mengalami kesulitan didalam memahami bahan ajar tersebut. Dalam hal ini multimedia presentasi sangat diperlukan dalam pembelajaran pendidikan agama Hindu pada topik pelajaran konsep kramaning sembah dan proses prinsip-prinsip hari suci agama Hindu di SMA Negeri 5 Denpasar sehingga dapat memperjelas pemahaman siswa terhadap topik materi tersebut.

\subsection{Pengelolaan Multimedia Presentasi dan Media Cetak dalam Pembelajaran Pendidikan Agama Hindu}

Pelaksanaan proses pembelajaran merupakan aplikasi dari silabus dan Rencana Pelaksanaan Pembelajaran (RPP) yang telah disusun sebelumnya. Pembelajaran yang dilakukan oleh guru pendidikan agama Hindu pada siswa SMA Negeri 5 Denpasar sangat memperhatikan kegiatan pengelolaan materi pembelajaran dan aktivitas belajar siswa, seperti yang terlihat selama proses pengamatan yang dilakukan oleh peneliti.

Pembelajaran pendidikan agama Hindu yang memanfaatkan multimedia presentasi dan media cetak adalah topik pembelajaran atau kompetensi dasar tentang konsep kramaning sembah dan proses prinsip-prinsip hari suci 
agama Hindu. Materi pelajaran tentang konsep kramaning sembah diberikan selama dua kali pertemuan yaitu pada pertemuan pertama dan kedua, sedangkan materi pelajaran tentang proses prinsip-prinsip hari suci agama Hindu diberikan selama dua kali pertemuan pada pertemuan ketiga dan keempat. Hasil observasi yang ditemukan selama observasi yang dilakukan peneliti, meliputi: kegiatan pendahuluan, kegiatan inti, dan kegiatan penutup.

\section{Kegiatan Pendahuluan}

Awal kegiatan pembelajaran, guru mempersilahkan siswa untuk menyiapkan buku teks pelajaran dan menyampaikan keadaan yang ada di lingkungan masyarakat yang berkaitan dengan materi pembelajaran tentang konsep kramaning sembah dan proses prinsip-prinsip hari suci agama Hindu dalam bentuk multimedia presentasi, selanjutnya guru memfasilitasi siswa melakukan interaktif, dan kemudian menampilkan tujuan pembelajaran yang hendak dicapai.

Setiap awal pertemuan pembelajaran guru melakukan kegiatan pendahuluan, hal tersebut dimaksudkan un-tuk membangkitkan motivasi dan memfokuskan perhatian siswa untuk berpartisipasi aktif dalam proses pembelajaran. Kegiatan pendahuluan yang dilakukan dalam pembelajaran yaitu menghubungkan materi pelajaran dengan kehidupan siswa di lingkungan keluarga dan masyarakat yang berkaitan dengan materi pelajaran tentang konsep kramaning sembah dan proses prinsip-prinsip hari suci agama Hindu. Seperti yang disampaikan guru pendidikan agama Hindu pada siswa SMA Negeri 5 Denpasar dalam kegiatan pendahuluan yaitu kegiatan persembahyangan sehari-hari dan pada hari-hari suci agama Hindu melalui penjelasan langsung dan tayangan slide video dari multimedia presentasi. Selanjutnya melakukan interaktif yang berkaitan dengan kegiatan yang ditampilkan melalui slide videoyang ada hubungannya dengan topik materi pelajaran, dengan tujuan untuk mengetahui pengalaman siswa terkait dengan materi yang akan disampaikan oleh guru.

Tujuan pembelajaran juga disampaikan pada kegiatan pendahuluan untuk memberikan arahan atau tujuan yang jelas terhadap materi pelajaran dan agar siswa memahami maksud dari mempelajari topik pembelajaran dalam kaitannya antara konsep kramaning sembah dan proses prinsip-prinsip hari suci agama Hindu dengan kehidupan siswa di lingkungan keluarga dan masyarakat. Mengetahui tujuan dan manfaat suatu topik pembelajaran terlebih dahulu, siswa akan lebih termotivasi untuk mempelajari topik materi tersebut karena merasa bermanfaat atau bermakna dalam kehidupan sehari-hari. Penyampaian tujuan pembelajaran yang dilakukan oleh guru, diikuti dengan penyampaian cakupan materi agar terdapat kejelasan didalam pencapaian tujuantujuan pembelajaran yang telah dijabarkan dalam RPP.

Kegiatan pendahuluan yang dilakukan guru seperti yang telah diuraikan di atas merupakan langkah awal untuk menumbuhkan motivasi belajar siswa. Hal itu sesuai dengan teori media menurut Briggs (Sadiman, 2008: 23) yang dikenal dengan taksonomi media berdasarkan rangsangan belajar. Multimedia presentasi yang digunakan untuk memfasilitasi kegiatan pendahuluan dalam pelaksanaan proses pembelajaran pendidikan agama Hindu pada siswa SMA Negeri 5 Denpasar adalah untuk memberikan stimulus atau rangsangan belajar sehingga dapat menumbuhkan motivasi belajar siswa.

\section{Kegiatan Inti}

Kegiatan inti yang dilakukan guru, yaitu menyajikan materi pelajaran dengan multimedia presentasi dan media cetak (buku teks pelajaran). Selama pembelajaran berlangsung diselingi dengan interaktif, peragaan, dan diskusi kelompok kecil. Interaktif dilakukan setelah mendengar penjelasan guru, mengamati sajian 
teks dan gambar. Peragaan keterampilan dilakukan setelah mengamati gambar dan peragaan guru, sedangkan diskusi kelompok kecil dilakukan dalam mencermati sajian gambar, suara, dan video.

Pelaksanaan kegiataninti yang dilakukan guru merupakan proses pembelajaran untuk mencapai Kompetensi Dasar (KD) dengan pendekatan yang interaktif, inspiratif, menyenangkan, dan menantang. Pendekatanpendekatan tersebut dimaksudkan untuk me-motivasi siswa agar berpartisipasi aktif dalam menumbuhkan prakarsa, kreativi-tas, dan kemandirian sesuai dengan bakat, minat dan perkembangan fisik serta psikologis siswa. Pendekatan-pendekatan yang dilakukan guru dalam proses pelaksanaan pembelajaran merupakan upaya untuk memotivasi siswa agar materi pelajaran yang disajikan memiliki kesesuaian dengan pembawaan siswa seperti perkembangan fisik dan psikologis. Kegiatan inti dalam pembelajaran pendidikan agama Hindu pada materi pelajaran tentang konsep kramaning sembah dan proses prinsip-prinsip hari suci agama Hindu, menggunakan multimedia presentasi, media cetak (buku teks pelajaran), metode yang disesuai-kan dengan karakteristik siswa dan mata pelajaran (metode ceramah variatif, diskusi, peragaan, dan penugasan). Proses pembelajaran yang dilakukan guru meliputi: proses eksplorasi, elaborasi, dan konfirmasi.

Pelaksanaan pembelajaran dengan pendekatan-pendekatan tersebut memiliki relevansi dengan teori motivasi biogenic theoris. Biogenic theoris menekankan pada mekanisme pembawaan biologis, seperti insting dan kebutuhan-kebutuhan biologis (Sardiman, 2007: 76). Demikian juga halnya dalam pembelajaran pendidikan agama Hindu yang memanfaatkan multimedia presentasi dan media cetak pada siswa SMA Negeri 5 Denpasar dengan menggunakan beragam pendekatan adalah untuk menyesuaikan dengan pembawaan siswa sehingga proses pembelajaran dapat berlangsung dengan optimal.

Proses eksplorasi adalah kegiatan untuk memperoleh pengalaman baru dari situasi yang baru (Depdiknas, 2001: 290). Proses eksplorasi yang dimaksud dalam kegiatan pembelajaran pendidikan agama Hindu terkait dengan penelitian ini adalah suatu proses yang dilakukan untuk memperoleh pengalaman baru melalui suatu kegiatan pembelajaran dengan situasi yang baru. Guru melibatkan siswa mencari informasi yang luas tentang konsep kramaning sembah dan proses prinsip-prinsip hari suci agama Hindu yang dipelajari melalui kegiatan interaktif setelah mengamati sajian materi dengan multimedia presentasi melalui tayangan slide-slide powerpoint dan membaca buku teks pelajaran atau bahan ajar pendidikan agama Hindu.

Guru mengelola pembelajaran dengan menggunakan beragam pendekatan pembela-jaran, seperti memadukan metode ceramah variatif, metode diskusi, dan metode peragaan, serta memadukan media pembelajaran berupa multimedia presentasi dan media cetak. Metode ceramah variatif digunakan untuk mengantarkan atau menjelaskan tayangan-tayangan materi pelajaran yang ada pada slide-slide multimedia presentasi dan isi buku teks pelajaran serta diselingi dengan tanya jawab sehingga pembelajaran menjadi lebih variatif dan interaktif. Metode diskusi digunakan untuk menumbuhkan pendapat siswa tentang topik yang dipelajari yang berhubungan dengan kehidupan siswa di lingkungan keluarga dan masyarakat. Diskusi yang dilakukan siswa sebatas diskusi kelompok kecil antara teman yang duduk berdekatan. Teknik diskusi semacam ini sangat tepat dilakukan karena siswa mengikuti pembelajaran sambil mengamati tayangan-tayangan slide powerpoint, mendengarkan penjelasan guru, dan sambil mencermati topik materi yang terdapat dalam bahan ajar, sehingga proses pembelajaran menjadi lebih efektif. Metode 
peragaan digunakan untuk memperagakan halhal yang berkaitan dengan topik materi pelajaran seperti peragaan sikap sembahyang dan melafalkan mantram panca sembah pada materi pelajaran tentang konsep kramaning sembah.

Guru memfasilitasi pembelajaran dengan beragam pendekatan agar terjadi interaksi antar siswa serta antara siswa dengan guru terhadap permasalahan yang muncul dari topik materi pelajaran yang berkaitan dengan lingkungan dan sumber belajar lainnya. Dalam menyajikan materi pelajaran, guru lebih menekankan pada pokok-pokok materi berupa teks, gambar, suara, dan video. Salah satu contoh yang dilakukan guru pada sub topik kramaning sembah tentang sarana persembahyangan, guru menunjukkan visual sarana persembahyang berupa kewangen dengan tayangan slide powerpoint, dengan stimulus tersebut siswa akan menyebut bentuk totalitas visual sarana tersebut dengan sebutan kewangen, bukan menyebutkan bagian-bagian dari kewangen. Bagian-bagian dari kewangen direspons setelah mengetahui bentuk keseluruhan dari kewangen, seperti kewangen terdiri dari kojong kewangen dengan daun pisang, sampian kewangen dengan daun kelapa, bunga, kembang rampe, uang kepeng, dan sebagainya serta memahami makna dari masing-masing komponen kewangen.

Berdasarkan teori belajar kognitif Gestalt menekankan bahwa kesan pertama dalam belajar adalah melalui pengamatan yang bersifat totalitas atau keseluruhan dan bagian-bagian akan muncul secara analitis (Sagala, 2008: 45). Penyajian materi pelajaran yang dilakukan guru yang telah diuraikan di atas memiliki relevansi dengan teori belajar kognitif Gestalt yang digunakan merujuk pelaksanaan pembelajaran pendidikan agama Hindu yang memanfaatkan multimedia presentasi dan media cetak. Siswa akan mendapatkan pemahaman atau pengertian terhadap materi yang dipelajari setelah mengamati obyek belajar secara totalitas. Proses pemahaman atau pengertian terhadap materi pelajaran, guru memberikan kesempatan kepada siswa secara aktif dalam setiap kegiatan pembelajaran, seperti mengajukan pertanyaan, menjawab pertanyaan teman, menjawab pertanyaan interaktif multimedia presentasi, menjawab pertanyaan guru, dan mengajukan pendapat. Selain itu guru juga memfasilitasi siswa dalam peragaan keterampilan yang berkaitan dengan topik materi pembelajaran seperti sikap sembahyang dan pengucapan/lafalan mantram kramaning sembah.

Elaborasi memiliki makna pendalaman pengetahuan (Depdiknas, 2001: 292). Proses elaborasi dalam pembelajaran pendidikan agama Hindu merupakan tindakan melakukan atau mengerjakan sesuatu secara tekun dan cermat untuk memperdalam pengetahuan dari konsep materi yang dipelajari. Proses elaborasi, guru memfasilitasi dengan memberikantugas-tugas yang bermakna seperti membaca, menulis, melafalkan, berdiskusi, dan memperagakan sesuatu yang berkaitan dengan topik materi pelajaran, untuk memuncul-kan gagasan baru baik secara lisan maupun tertulis. Hal ini dilakukan untuk menumbuhkan minat baca, berpendapat, musyawarah, dan unjuk keterampilan terhadap suatu permasalahan yang ada pada topik materi pelajaran sehingga siswa akan menjadi terbiasa menggali informasi, menganalisis suatu permasalahan, memberikan pendapat, dan terampil melakukan suatu kegiatan.

Memfasilitasi belajar melalui diskusi merupakan aktivitas belajar untuk memberi kesempatan untuk berpikir, menga-nalisis, menyelesaikan masalah, dan bertindak tanpa rasa takut. Pemberian masalah tentang topik materi akan melatih siswa untuk berpikir, mengalisis, menemukan jawaban atas masalah, dan mengemukakan pendapat secara kooperatif dan kolaboratif. Hal tersebut sesuai dengan teori belajar konstruktivisme (dalam Sardiman, 2007: 37), yaitu menekankan bahwa 
pengetahuan individu itu adalah konstruksi (bentukan) individu itu sendiri. Melalui diskusi siswa akan dapat menumbuhkan proses berpikir dalam mengkonstruksi suatu pendapat untuk menemukan suatu jawaban yang tepat terhadap permasalahan yang hendak dipecahkan.

Memfasilitasi belajar melalui peragaan merupakan aktivitas belajar untuk memberikan kesempatan kepada siswa dalam melatih keterampilan fisik. Terkait dengan topik materi pelajaran pendidikan agama Hindu tentang konsep kramaning sembah, siswa dapat memperagakan berbagai sikap sembahyang dan melafalkan mantram kramaning sembah. Aktivitas belajar tersebut dimaksudkan guru untuk memperoleh perubahan sikap atau perilaku terhadap sikap-sikap sembahyang dan pengucapan mantram-mantram kramaning sembah yang benar. Menurut teori belajar Thorndike (Uno, 2007: 11) yang disebut teori belajar tingkah laku, bahwa belajar merupakan proses interaksi antara stimulus dan respons. Belajar yang menekankan pada perubahan tingkah laku melalui interaksi antara stimulus dan respons, guru melakukannya melalui penugasan dan latihan-latihan setelah guru memfasilitasi dengan pembelajaran yang memanfaatkan multimedia presentasi dan media cetak. Misalnya setelah mengamati visualisasi topik pembelajaran tentang sikap sembahyang dan peragaan guru, siswa merespons dan memperagakan sikap tersebut serta setelah mendengar dan membaca mantram panca sembah, siswa merespons dengan melafalkan mantram-mantram tersebut. Proses terjadinya interaksi antara stimulus dan respons dalam pembelajaran pendidikan agama Hindu dengan memanfaatkan multimedia presentasi dan media cetak menyebabkan terjadinya perubahan tingkah laku pada diri siswa.

Hal-hal lain yang juga dilakukan oleh guru dalam proses elaborasi terhadap pembelajaran pendidikan agama Hindu tentang konsep kramaning sembah dan proses prinsip-prinsip hari suci agama Hindu yaitu memfasilitasi siswa berkompetisi secara sehat untuk meningkatkan prestasi belajar, memfasilitasi siswa membuat laporan eksplorasi yang dilakukan secara lisan maupun tertulis, baik individual maupun kelompok, memfasilitasi siswa untuk menyajikan hasil kerja, dan memfasilitasi siswa melakukan kegiatan atau peragaan keterampilan. Proses elaborasi dengan memfasilitasi siswa dimaksudkan agar siswa dapat meningkatkan prestasi belajar dengan cara-cara yang jujur, mandiri dan bertanggung jawab, siswa mampu menyusun laporan kegiatan belajar, menyampaikan/menyajikan hasil kegiatan belajar, dan melakukan kegiatankegiatan yang berhubungan dengan topik pembelajaran untuk menumbuhkan rasa bangga dan percaya diri. Memfasilitasi siswa dalam proses pembelajaran merupakan proses elaborasi untuk memenuhi kebutuhan fisiologis siswa dalam belajar sehingga timbul rasa nyaman dan senang/bangga dalam mengikuti proses pembelajaran. Hal tersebut sesuai dengan teori motivasi menurut Maslow (dalam Uno, 2007: 6) bahwa kebutuhan manusia secara hierarkis semuanya laten dalam diri manusia. Kebutuhan tersebut meliputi kebutuhan fisiologis, kebutuhan rasa aman, kebutuhan kasih sayang, kebutuhan dihargai dan dihormati, dan kebutuhan aktualitas diri. Rangkaian dari proses elaborasi dalam pembelajaran merupakan proses penerapan dari hasil proses eksplorasi dengan memfasilitasi berbagai kebutuhan belajar siswa, sehingga dapat memberikan kepuasan belajar pada setiap siswa.

Proses konfirmasi merupakan penegasan terhadap topik materi pembelajaran. Kegiatan konfirmasi yang dilakukan guru yaitu:memberikan umpan balik dan penguatan dalam bentuk lisan, tulisan, maupun peragaan terhadap keberhasilan siswa, memberikan konfirmasi terhadap hasil eksplo-rasi dan elaborasi siswa melalui ber-bagai sumber, memfasilitasi siswa melakukan refleksi untuk memperoleh 
pengalaman belajar yang telah dilakukan, dan memfasilitasi siswa untuk memperoleh pengalaman yang bermakna dalam mencapai kompetensi dasar. Proses konfirmasi bertujuan untuk membantu siswa dalam menyelesaikan masalah, memberi penegasan terhadap jawaban dari permasalahan yang berkaitan dengan topik pembelajaran, memberi acuan agar siswa dapat melakukan pengecekan hasil eksplorasi, memberi informasi untuk bereksplorasi lebih jauh, dan memberikan motivasi kepada siswa yang kurang atau belum berpartisipasi aktif.

\section{Kegiatan Penutup}

Kegiatan penutup yang dilakukan guru, yaitu menyimpulkan isi pembelajaran dan memberikan pertanyaan/tugas. Kegiatan penutup merupakan kegiatan yang dilakukan un-tuk mengakhiri aktivitas pembelajaran dalam bentuk rangkuman atau kesimpul-an materi pelajaran, penilaian dan refleksi, umpan balik, dan tindak lanjut. Dalam kegiatan penutup, guru bersama-sama dengan siswa membuat rangkuman/simpulan pelajaran, melakukan penilaian dan refleksi terhadap kegiatan yang sudah dilaksanakan secara konsis-ten dan terprogram, dan memberikan umpan balik terhadap proses dan hasil pembelajaran. Berdasarkan hasil penilaian yang diperoleh siswa, selanjutnya guru merencanakan kegiatan tindak lanjut dalam bentuk pembelajaran remidi kepada siswa yang belum tuntas, program pengayaan kepada siswa yang telah tuntas, dan memberikan tugas balik sesuai dengan hasil belajar siswa, dan menyampaikan rencana pembelajaran pada pertemuan berikutnya.

Berdasarkan analisis terhadap pengelolaan multimedia presentasi dan media cetak dalam pelaksanaan proses pembelajaran pendidikan agama Hindu pada topik materi perajaran konsep kramaning sembah dan proses prinsip-prinsip hari suci agama Hindu, dapat disimpulkan bahwa kegiatan pembelajaran dilakukan yaitu: kegiatan pendahulan, kegiatan inti, dan kegiatan penutup. Kegiatan pendahuluan adalah kegiatan awal untuk menumbuhkan motivasi belajar siswa. Kegiatan inti adalah kegiatan untuk memfasilitasi pelaksanaan proses pembelajaran dengan multimedia presentasi dan media cetak yang meliputi kegiatan penyajian materi pelajaran, interaktif, diskusi, dan peragaan keterampilan. Kegiatan penutup adalah kegiatan untuk mengakhiri pembelajaran dengan menyimpulkan materi yang telah dipelajari siswa.

\subsection{Penilaian Hasil Belajar Siswa dalam Pembelajaran Pendidikan Agama Hindu yang Memanfaatkan Multimedia Presentasi dan Media Cetak}

Penilaian dilakukan oleh guru terhadap hasil pembelajaran untuk mengukur tingkat pencapaian kompetensi siswa, serta digunakan sebagai bahan penyusunan laporan kema-juan hasil belajar, dan memperbaiki proses pembelajaran. Hasil belajar merupakan produk belajar yang ditunjukkan siswa setelah mengikuti proses pembelajaran. Produk belajaryang dimaksudkan dalam penelitian ini adalah hasil belajar siswa setelahmengikuti pembelajaran pendidikan agama Hindu tentang konsep kramaning sembah dan proses prinsip-prinsip hari suci agama Hindu melalui proses penilaian.

Kesiapan belajar siswa secara keseluruhan menunjukkan kesiapan belajar yang positif. Hal tersebut terlihat pada seluruh siswa yang hadir telah siap dengan perlengkapan belajar seperti buku teks pelajaran, buku catatan, alat tulis, dan tugas-tugas yang telah diberikan sebelumnya, sedangkan perilaku dalam mengikuti pelajaran juga tergolong aktif dan sopan. Hasil observasi terhadap kegiatan proses dalam pembelajaran yang memanfaatkan multimedia presentasi dan media cetak menunjukkan aktivitas belajar yang responsif dan interaktif, seperti aktif bertanya 
dan menjawab pertanyaan, aktif berdiskusi, aktif memperagakan perintah guru, dan mengerjakan tugas yang diberikan guru.

Hasil belajar siswa dalam memahami konsep kramaning sembah dan proses prinsip-prinsip hari suci agama Hindu, secara keseluruhan dari penilaian yang dilakukan guru terhadap pembelajaran yang memanfaatkan multimedia presentasi dan media cetak menunjukkan hasil belajar yang lebih baik dari kegiatan belajar sebelumnya yang tidak memanfaatkan multimedia presentasi. Hasil belajar tersebut diperoleh melalui pelaksanaan ulangan harian dalam bentuk tes obyektif pilihan ganda. Hasil tes yang diperoleh siswa dikonfirmasikan dengan standar ketuntasan belajar minimal. Standar ketuntasan belajar minimal mata pelajaran pendidikan agama Hindu, berdasarkan Kurikulum Tingkat Satuan Pendidikan (KTSP) SMA Negeri 5 Denpasar adalah 70. Siswa yang memperoleh hasil belajar pendidikan agama Hindu kurang dari 70 dinyatakan belum tuntas, sedangkan yang sudah mencapai hasil belajar $70 \mathrm{ke}$ atas dinyatakan tuntas.

Peningkatan hasil belajar yang terjadi disebabkan bahwa pembelajaran dengan multimedia presentasi dan media cetak siswa dibawa pada kondisi kongkrit dan interaktif yaitu kondisi yang berhubungan dengan keseharian siswa. Pemanfaatan multimedia presentasi dan media cetak dalam pembelajaran pendidikan agama Hindu pada topik konsep kramaning sembah dan proses prinsip-prinsip hari suci agama Hindu telah mampu memenuhi fungsi media dalam pembelajaran yaitu dapat mengakomodasikan berbagai tipe atau gaya belajar siswa. Keadaan itu sesuai dengan teori media menurut Rudy Bretz (Munadi, 2008: 52), yaitu taksonomi media berdasarkan indera yang terlibat. Penggunaan teks, gambar, dan video dalam slide-slide powerpoint dapat memenuhi fungsi indera penglihatan, sedangkan penggunaan suara/audio dan video dapat memenuhi fungsi indera pendengaran. Hal tersebut juga memliliki relevansi dengan teori media menurut Gagne (Munadi, 2008: 51), yaitu taksonomi media berdasarkan fungsi pembelajaran. Pemanfaatan multimedia dan media cetak dapat memenuhi fungsi pembelajaran sebagai pelontar stimulus belajar, penarik minat belajar, contoh perilaku belajar, memberi kondisi eksternal, penuntun cara berpikir, pemasukan alih ilmu, penilai prestasi, dan pemberi umpan balik. Proses pembelajaran melalui media tersebut, siswa dapat melihat kondisi yang sebenarnya melalui visualisasi multimedia presentasi yang berhubungan dengan kenyataan yang ada di lingkungan keseharian siswa. Pembelajaran dengan memanfaatkan multimedia presentasi dan media cetak mampu mengantarkan kondisi belajar yang interaktif, menarik, dan menyenangkan sesuai dengan fungsi pembelajaran. Sedangkan kondisi pembelajaran hanya memanfaatkan media cetak, pemahaman siswa lebih bersifat verbal, kegiatan pembelajaran lebih banyak bersifat naratif sehingga siswa sulit memahami informasi guru dan sulit melakukan interaktif terhadap permasalahan yang dihadapinya.

Ditinjau dari konsep media pembelajaran menurut Arsyad (2008) bahwa pemanfaatan multimedia berbasis komputer bertujuan untuk menyajikan informasi dalam bentuk yang menyenangkan, menarik, mudah dimengerti, dan jelas. Munadi (2008) menyebutkan bahwa pemanfaatan multimedia presentasi menyebabkan kegiatan presentasi menjadi sangat mudah, dinamis, dan sangat menarik. Menurut Anitah (2009) bahwa multimedia merupakan kegiatan interaktif yang sangat tinggi, mengajak pebelajar atau siswa untuk mengikuti proses pembelajaran, sedangkan menurut Mayer (2009) bahwa belajar melalui multimedia dengan membuat keterkaitan antara kata dan gambar, siswa bisa menciptakan pemahaman lebih dalam daripada sekadar belajar dari katakata saja atau gambar-gambar saja. Pandangan dari keempat pakar media pembelajaran 
tersebut, mengindikasikan bahwa pembelajaran dengan menggunakan multimedia adalah memadukan berbagai media untuk menyajikan informasi yang lebih menyenangkan, menarik, mudah dimengerti, dan interaktif dengan tujuan untuk meningkatkan hasil belajar siswa.

Terkait dengan penelitian ini, pembelajaran yang dilakukan oleh guru pendidikan agama Hindu yaitu memanfaatkan multimedia presentasi yang dikombinasikan dengan media cetak (buku teks pelajaran) pada materi pelajaran konsep kramaning sembah dan proses prinsip-prinsip hari suci agama Hindu. Hasil belajar yang ditunjukkan terjadi kesesuaian dengan konsep yang dikemukakan oleh keempat pakar di atas. Hal tersebut terbukti bahwa hasil belajar siswa SMA Negeri 5 Denpasar dalam pembelajaran pendidikan agama Hindu pada topik konsep kramaning sembah dan proses prinsip-prinsip hari suci agama Hindu terjadi peningkatan dari sebelum dan sesudah pemanfaatan multimedia presentasi dan media cetak. Jadi dengan demikian, pembelajaran yang dilakukan guru dalam pembelajaran pendidikan agama Hindu pada siswa SMA Negeri 5 Denpasar telah mengembangkan pembelajaran yang efektif, bermakna dan menyenangkan, sehingga upaya untuk meningkatkan hasil belajar dapat tercapai sesuai dengan harapan.

\section{SIMPULAN}

Pemanfaatan multimedia presentasi dan media cetak dalam pembelajaran pendidikan agama Hindu untuk meningkatkan hasil belajar siswa SMANegeri 5 Denpasar, nampak dalam: (1) kegiatan pengelolaan materi pembelajaran dalam pelaksanaan proses pembelajaran pada topik materi pelajaran konsep kramaning sembah dan proses prinsip-prinsip hari suci agama Hindu, meliputi: kegiatan pendahuluan, kegiatan inti, dan kegiatan penutup. Kegiatan pendahuluan dilakukan sebagai kegiatan awal untuk menumbuhkan motivasi belajar siswa. Kegiatan inti dilakukan dengan memfasilitasi pelaksanaan proses pembelajaran dengan multimedia presentasi dan media cetak yang meliputi kegiatan penyajian materi pelajaran, interaktif, diskusi, dan peragaan keterampilan. Kegiatan penutup dilakukan untuk mengakhiri pembelajaran dengan menyimpulkan materi yang telah dipelajari siswa; dan (2) Kegiatan penilaian dilakukan terhadap penilaian proses pembelajaran dan penilaian terhadap pengetahuan dan pemahaman konsep materi yang dipelajari siswa dengan menggunakan tes ulangan harian. Pemanfaatan multimedia presentasi dan media cetak dalam proses pembelajaran ternyata mampu meningkatkan aktivitas belajar, dan ketuntasan hasil belajar siswa.

Kegiatan pembelajaran mengaplikasi teori belajar, teori motivasi, dan teori media. Khususnya pada teori belajar, yaitu: teori belajar Thorndike, konstruktivisme, dan kognitif Gestalt. Teori belajar Thorndike diaplikasikan melalui latihan-latihan dan peragaan-peragaan untuk menumbuhkan terjadinya perubahan tingkah laku, teori belajar konstruktivisme diaplikasikan melalui kegiatan diskusi terhadap permasalahan yang muncul dari topik pembelajaran untuk membangun pendapat siswa dalam menemukan jawaban, dan teori belajar kognitif Gestalt diaplikasikan melalui pokok-pokok materi pelajaran berupa teks, gambar, suara/audio, dan video untuk menumbuhkan pemahaman terhadap keseluruhan dari obyek atau materi pelajaran dan baru kemudian bagian-bagian dari obyek atau materi pelajaran yang dipelajari.

\section{Daftar Pustaka}

Anitah, Sri. 2009. Media Pembelajaran. Surakarta: UNS Press.

Arsyad, Azhar. 2008. Media Pembelajaran. Jakarta: PT. Raja Grafindo Persada.

Budiningsih, Asri C. 2005. Belajar dan Pembelajaran. Jakarta: Rineka Cipta. 
Danim, Sudarwan. 2008. Media Komunikasi Pendidikan. Jakarta : PT. Bumi Aksara.

Depdiknas. 2001. Kamus Besar Bahasa Indonesia Edisi Ketiga. Departemen Pendidikan Nasional. Jakarta: Balai Pustaka.

Dimyati dan Mudjiono. 2006. Belajar dan Pembelajaran. Jakarta: Rineka Cipta.

Djamarah, Syaiful Bahri. 2008. Psikologi Belajar. Jakarta: Rineka Cipta.

Elmubarok, Zaim. 2008. Membumikan Pendidikan Nilai. Bandung: Alfabeta.

Fatah, Syukur NC. 2008. Teknologi Pendidikan. Semarang: Rasail Media Group.

Hamalik, Oemar. 2001. Perencanaan Pengajaran Berdasarkan Pendekatan Sistem. Jakarta: PT. Bumi Aksara.

Hamalik, Oemar. 2004. Proses Belajar Mengajar. Jakarta: Bumi Aksara.

Hasbulah. 2007. Otonomi Pendidikan, Kebijakan Otonomi Daerah dan Implikasinya terhadap Penyelenggaraan Pendidikan. Jakarta: PT. Raja

Grafindo.

Imron, Ali. 2008. Kebijaksanaan Pendidikan Indonesia, Proses, Produk \& Masa Depannya. Jakarta: Bumi Aksara.

Jaman, I Gede. 2001. Tri Hita Karana dalam Konsep Hindu. Jakarta: Pustaka Bali Post.

Mayer, Richard E. 2009. Multi-Media Learning, Prinsip-Prinsip dan Aplikasi. Yogyakarta: Pustaka Pelajar

Munadi, Yudhi. 2008. Media Pembelajaran; Sebuah Pendekatan Baru. Jakarta: Gaung Persada Press.

Munir. 2008. Kurikulum Berbasis Teknologi Informasi dan Komunikasi. Bandung: Alfabeta.
Nasution S. 2003. Berbagai Pendekatan Proses Belajar Mengajar. Jakarta: Gramedia.

Pidarta, Made. 2007. Landasan Kependidikan, Jakarta: Rineka Cipta.

Rohani, Ahmad HM, 2004. Pengelolaan Pengajaran. Jakarta: PT. Rineka Cipta.

Sadiman, Arief S., dkk. 2008. Media Pendidikan, Pengertian, Pengembangan, dan Pemanfaatannya. Jakarta: PT. Raja Grafindo Persada.

Sagala, Syaiful. 2008. Konsep dan Makna Pembelajaran. Bandung: Alfabeta.

Sardiman. 2007. Interaksi \& Motivasi Belajar Mengajar. Jakarta: PT. Raja Grafindo Persada.

Setiawan, Benni, 2008. Agenda Pendidikan Nasional. Jogjakarta: Ar-Russ Media.

Sidi, Indra Djati. 2001. Menuju Masyarakat Belajar, Menggagas Paradigma Baru Pendidikan. Jakarta: Paramadina \& PT. Logos Wacana Ilmu.

Slameto. 2001. Evaluasi Pendidikan. Jakarta: Bumi Aksara.

Sobry, Sutikno. 2004. Model Pembelajaran Interaksi Sosial, Pembelajaran Efektif dan Ritorika. Mataram: NTP Press.

Sudjana, Nana. 2009. Penilaian Hasil Proses Belajar Mengajar. Bandung: PT. Rosdakarya.

Suandra, Made. 1991. Tuntunan Kramaning Sembah. Denpasar: Upada Sastra.

Sudarsana, I. K. (2017). Interpretation Meaning of Ngaben for Krama Dadia Arya Kubontubuh Tirtha Sari Ulakan Village Karangasem District (Hindu Religious Education Perspective). Vidyottama Sanatana: International Journal of Hindu Science and Religious Studies, 1(1), 1-13. 
Sukardi, MS. 2008. Evaluasi Pendidikan Prinsip dan Operasionalnya. Jakarta: PT. Bumi Akasara.

Suryosubroto. 2004. Manajemen Pendidikan di Sekolah. Jakarta: Rineka Cipta.

Syah, Muhibbin. 2007. Psikologi Belajar. Jakarta: PT. Raja Grafindo Persada.

Tilaar, H.A.R. 2004. Paradigma Baru Pendidikan Nasional. Jakarta: PT. Rineka Cipta.

Tim BSNP. 2006. "Panduan Penyusunan Kurikulum Tingkat Satuan Pendidikan Jenjang Pendidikan Dasar dan Menengah". Badan Standar Nasional Pendidikan Jakarta.

Tim Penyusun. 2008. Pedoman Penjamin Mutu Sekolah/Madrasah Bertarap Internasional pada Jenjang Pendidikan Dasar dan Menengah". Departemen Pendidikan Nasional Jakarta.

Titib, I Made. 1998. Veda Sabda Suci Pedoman Praktis Kehidupan. Surabaya: Paramita.
Uno, Hamzah B. 2007. Teori Motivasi \& Pengukurannya. Jakarta: Bumi Aksara.

Wiana, I Ketut. 2007. Tri Hita Karana Menurut Konsep Hindu. Surabaya: Paramita.

Wisarja, I. K., \& Sudarsana, I. K. (2017). Praksis Pendidikan Menurut Habermas (Rekonstruksi Teori Evolusi Sosial Melalui Proses Belajar Masyarakat). Indonesian Journal of Educational Research, 2(1), 18-26.

Wisarja, I. K., \& Sudarsana, I. K. (2017). REFLEKSI KRITIS IDEOLOGI PENDIDIKAN KONSERVATISME DAN LIBRALISME MENUJU PARADIGMA BARU PENDIDIKAN. Journal of Education Research and Evaluation, 1(4), 283-291.

Zamroni. 2003. Paradigma Pendidikan Masa Depan. Jakarta: Bigraf Publishing. 